\title{
COMPARISON OF EYE PROTECTION WITH METHYLCELLULOSE AND PARAFFIN OINTMENTS DURING GENERAL ANAESTHESIA
}

\author{
Niels Bo Bøggild-Madsen, Paul Bundgarrd-Nielsen, Ulf Hammer And Bente Jakobsen
}

\begin{abstract}
A total of 120 patients who were all anaesthetized for more than 90 minutes were given eye protection with paraffin-based oculentum simplex, $\mathrm{Ph}$. Nord. 63, in one eye, and water-based four per cent methylcellulose in the other. Anaesthesia was conducted with halothane, or thiopentone and meperidine. or by a neurolept technique. Peri-ocular oedema and reaction in the conjunctiva resembling conjunctivitis was less pronounced after methylcellulose. When both paraffin-based ointment and halothane anaesthesia were used, there were signs of drug interaction, as the patients' conjunctivae were now distinctly red. In all three types of anaesthesia, methylcellulose produces a firm gluing of the eyelids with the result that the eye is not dried out and the eye is protected mechanically so that foreign bodies and corneal abrasions are avoided. There were no untoward effects of methylcellulose. It is concluded that methylcellulose four per cent provides better eye protection than paraffin during general anaesthesia.
\end{abstract}

KEY WORDS: EYE, protection, methylcellulose ointment.

IN ANAESTHETIZED PATIENTS there is a risk of eye damage caused by two factors. Firstly, there can be corneal abrasion because the normal eyelid reflexes are suppressed and because there is no perception of pain if something happens to touch the eye. ${ }^{1,2,3}$ Secondly, there is a risk of drying of the cornea ${ }^{4}$ especially as the production of tears is decreased during general anaesthesia. ${ }^{5}$ Both may lead to a protracted eye disability or even to blindness. ${ }^{1,3}$ The risk is pronounced if the anaesthetist cannot see the eyes, as in an operation where the patient's face is turned away or covered by drapes. In such cases it is recommended to put a drop of oil or some paraffin-based ointment into the conjunctival sac before or immediately after the induction of anaesthesia. ${ }^{2,5}$ However, it is common to see patients with swollen, red itching eyes the day after the anaesthetic even if protective ointment has been applied. It must therefore be questioned whether conventional paraffin ointments are ideal. Norn ${ }^{6}$ investigated awake patients and recommended

Niels Bo Bøggild-Madsen, M.D., Department of Anaesthesiology; Paul Bundgaard-Nielsen and Ulf Hammer, Department of Pharmacy; Bente Jakobsen, Nurse in charge of the Recovery Ward, Department of Anaesthesiology, University Hospital of Aarhus, Kommunehospitalet, DK-8000 Aarhus C, Denmark.

Address reprint requests to: Niels Bo BøggildMadsen, M.D., Department of Anaesthesiology, University Hospital of Aarhus, Kommunehospitalet, DK-8000 Aarhus C, Denmark. that paraffin should not be used in the eye, as it breaks down the precorneal film which normally protects the cornea from drying out. In an in vitro study we found that halothane is dissolved 40 times as easily in paraffin eye ointment as in water-based ointment consisting of four per cent methylcellulose. Theoretically, under halothane anaesthesia there is a risk of getting a huge concentration of halothane in the eye when it is treated with paraffin ointment. ${ }^{7}$ If this happens, halothane may irritate the conjunctivae and the eyes will become red. Halothane does not normally irritate mucous membranes, ${ }^{8}$ but it might do so if the concentration and the exposure time are increased. The purpose of this investigation was to supplement our in vitro study to see if clinical symptoms developed in the eye reflecting the strong affinity of halothane for paraffin. We chose to make a comparison with methylcellulose which, in our in vitro study, practically did not dissolve halothane. ${ }^{\text {? }}$

Others have mentioned methylcellulose as a protective agent during anaesthesia, ${ }^{5.9}$ but the 0.5 per cent solution used was not very efficient, as it was so thin that it ran out of the eyes too fast. ${ }^{5}$

In a pilot study we found that four per cent methylcellulose remained in the eye, so it was possible to compare it with our usual paraffinbased eye ointment, oculentum simplex, $\mathrm{Ph}$. Nord. $63^{10}$ which corresponds with the eye ointments most used for all purposes. 


\section{Methods and Material}

The investigation included all patients operated upon during three months in the departments of general surgery, jaw surgery, plastic surgery and orthopedic surgery, when the anaesthesia was expected to last 90 minutes or more. Informed consent was obtained from each patient.

The series investigated consisted of $120 \mathrm{pa}-$ tients. Forty-five were adult males, 71 adult females and four were children under 12 years of age. Patients ranged in age from 15 days to 90 years, with only one under four years of age.

Twelve patients selected in advance by a randomization procedure had both eyes treated with the same ointment, either paraffin based ( 7 cases) or water based ( 5 cases), and constituted a "null group". The remaining 108 patients had their two eyes treated with different ointments, and constituted a "main group". Two were excluded because of preceding eye disease, four because of incomplete anamnesis and three because the operation did not last 90 minutes. No operation on the head was included except operations on the teeth and the mandible. The patients all had tracheal intubation but the tube was not allowed to draw the face awry. All patients were lying in a neutral position on their backs. The faces were not covered. The anaesthetist was not allowed to open the patient's eyes during the anaesthetic.

Two types of ointment of the same colour and consistency were prepared and randomly coded. One was the water-based methylcellulose four per cent $(W),{ }^{7}$ the other a clear paraffin-based ointment, oculentum simplex, Ph. Nord. $63(\mathrm{P})^{10}$ consisting of liquid parafin 20 per cent and yellow soft paraffin 80 per cent.

The anaesthetist applied the ointment into the conjunctival sacs immediately after tracheal intubation. A doctor studied the eyes of the patients 85-95 minutes later. In all tests the two eyes of the same patient were compared. The following parameters were investigated in the order mentioned:

Oedema $a_{1}$ : The back ends of two hard cannulae were pressed against the margo infraobitalis, compressing the skin. The side showing more persistent skin depression was judged to have greater oedema.

Gluing of the eyelids: The eyes were now opened, and it was noted which eye was most difficult to open.
Pink eye $e_{1}$ : A possible difference in the degree of conjunctival injection was noted.

The nurse in charge of the recovery ward checked the patients one hour after arrival in the recovery ward. The following three parameters were noted:

Oedema $_{2}$ : The possible difference in the degree and oedema of the eyelids was assessed by inspection only.

Pink Eye $e_{2}$ : Any difference in conjunctival injection in the two eyes was noted.

Blurred vision: Patients over four years of age were asked if vision was blurred in one eye or the other.

Premedication: Premedication was meperidine and atropine or morphine and scopolamine, occasionally in combination with a small dose of diazepam.

Anaesthesia: Anaesthesia was conducted with halothane, or thiopentone and meperidine or by a neurolept technique. For purposes of comparison of the occurrence of ocular symptoms the patients were divided into a group which had halothane and a group without halothane (Table I). Scavenging of the anaesthetic gases was always done according to the requirements of the Danish law.

\section{Results And Statistics}

The primary results are shown in Table I.

It was shown that a high incidence of complications is related to and caused by the use of the hydrophobic paraffin-based ointment. It was demonstrated that halothane does in fact have an effect on the occurrence of pink eyes.

The proportion of patients expected to benefit by a general change-over from $\mathrm{P}$ to $\mathrm{W}$ may be estimated. The results of such calculations are given in Figure 1 . Corresponding to all parameters $W$ was better than $P$, but the advantage of $W$ was not of the same magnitude in all the parameters. W > P per cent on the curve expresses how many patients in a population are expected to be advantaged by using $W$ instead of $P$.

\section{Discussion}

The oedema of the eye surroundings after about 90 minutes of anaesthesia was not always very distinct immediately, but by the method used it was demonstrated that 84 per cent of the patients had less oedema with $\mathrm{W}$ as compared to $P$. 
TABLE I

\begin{tabular}{|c|c|c|c|c|c|}
\hline \multirow[b]{2}{*}{ Symptoms } & & \multirow[b]{2}{*}{ Halothane } & \multicolumn{2}{|c|}{$\begin{array}{l}\text { Symptoms most pronounced } \\
\text { in the eye treated with }\end{array}$} & \multirow{2}{*}{$\begin{array}{l}\text { Identical } \\
\text { both eyes }\end{array}$} \\
\hline & & & Paraffin & Methylcellulose & \\
\hline Oedema, & & $\begin{array}{l}+ \\
-\end{array}$ & $\begin{array}{l}44 \\
34\end{array}$ & $\begin{array}{l}1 \\
1\end{array}$ & $\begin{array}{l}18 \\
10\end{array}$ \\
\hline Oedema $_{2}$ & 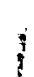 & $\begin{array}{l}+ \\
-\end{array}$ & $\begin{array}{l}28 \\
20\end{array}$ & $\begin{array}{l}3 \\
1\end{array}$ & $\begin{array}{l}32 \\
24\end{array}$ \\
\hline Pink eye & & $\begin{array}{l}+ \\
-\end{array}$ & $\begin{array}{r}34 \\
7\end{array}$ & $\begin{array}{l}2 \\
1\end{array}$ & $\begin{array}{l}27 \\
37\end{array}$ \\
\hline Pink cye ${ }_{2}$ & & $\begin{array}{l}+ \\
-\end{array}$ & $\begin{array}{r}12 \\
8\end{array}$ & $\begin{array}{l}2 \\
5\end{array}$ & $\begin{array}{l}49 \\
32\end{array}$ \\
\hline Blurred vision & & $\begin{array}{l}+ \\
-\end{array}$ & $\begin{array}{r}6 \\
10\end{array}$ & $\begin{array}{l}1 \\
0\end{array}$ & $\begin{array}{l}56 \\
34\end{array}$ \\
\hline
\end{tabular}

Number of patients showing symptoms indicated with each eye ointment with $(+)$ and without $(-)$ halothane. Total patients 108 .

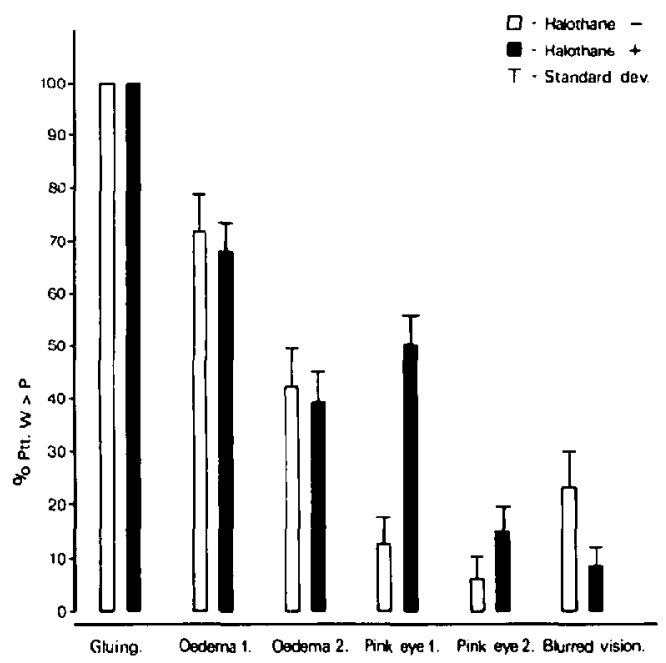

Figure 1 in all tests four per cent methylcellulose (W) was better than paraffin (P). \% Ptt. W > P expresses the degree of advantage of using $W$ instead of P. All patients will get better gluing of the eyelids by using $W$.

In all cases, $W$ glued the eyelids and the cilia together more firmly than did P. The gluing is a great advantage as evaporation from the eye is prevented and foreign bodies cannot enter the eyes. Externally a firm crust is formed, binding the cilia to the skin; but internally on the bulbus oculi side of the eyelids $W$ is smooth. If the sealing is broken, for example if the eye is opened during anaesthesia, some extra ointment must be applied to the eye to restore the gluing effect.

After 90 minutes of anaesthesia the eyes were opened. The gluing of the eye treated with $W$ was very evident, so there was no longer much doubt about which eye was treated with $W$. Consequently, the judgement of the colouring of the eyes was not free of bias. However, the clinical comparison was made as correct as possible. $W$ was found to be 15 per cent better than $P$ when halothane was not given, but 63 per cent better when halothane was used. It is likely that the injected conjunctiva is a result of drug interaction between halothane and paraffin. One might suppose that halothane gets into the ointment from the blood vessels and is retained in the ointment in a concentrated solution. The halothane could not come from pollution of the air in the room as all the patients were intubated and effective gas scavenging equipment was used. In an in vitro study, we have shown that halothane is very quickly dissolved in a concentrated form in paraf. fin, but not in methylcellulose. ${ }^{7}$ This phenomenon seems to have clinical relevance.

One hour after awakening from anaesthesia there was no longer any drug interaction, but $W$ was still better than $P$ in 10 per cent of the patients.

The oedema was assessed by inspection only in the recovery ward. When $\mathbf{P}$ was used, there was marked oedema.

Blurred vision is more difficult to interpret, as this parameter depends on the patient's subjective feelings and many of them were more or less confused one hour after anaesthesia and, in one case, too young to answer. Still $W$ was felt more comfortable than $\mathbf{P}$, but after halothane the advantage was not so pronounced. 


\section{CONCLUSIONS}

The investigation shows that the water-based methylcellulose four per cent offers better protection of the eyes during general anaesthesia than the paraffin-based oculentum simplex, Ph.Nord. 63. There is less oedema of the eye surroundings and less redness of the conjunctivae both during and after the anaesthesia. The most distinct conjunctival injection is seen when halothane anaesthesia and paraffin-based ointment are administered. This combination should therefore probably be warned against. Long lasting harmful effects of paraffin after anaesthesia have never been described; it is used daily in many countries both for protection of eyes and as a base for eye medication such as antibiotics.

There was no difference in the symptoms of drug interaction in the patients who received neurolept analgesia and in those who had thiopentone anaesthesia. The most important advantage of $W$ is that it keeps the eyelids firmly closed by gluing.

A further advantage is that, using methylcellulose, isotonic saline is added to each eye ${ }^{7}$ to supplement the amount of tears that is otherwise decreased because of the anaesthesia itself. ${ }^{s}$

No side effects of methylcellulose four per cent were seen. There will hardly be any as the drug is not absorbed through and does not influence the skin and mucous membranes. For many years methylcellulose eye drops have been used several times daily without problems in patients with decreased tear production. ${ }^{11,12}$ During anaesthesia the patients' eyes should be treated with methylcellulose four per cent in all cases where the patient tends to sleep with the eyes not closed spontaneously and when the anaesthetist cannot observe the eyes constantly.

\section{REFERENCES}

1. Wylie, W.D. \& Churchill-Davidoson, H.C. A practice of anaesthesia, p. 1029. London: LoydLuke Ltd. (1978).

2. LEE, J.A. \& ATKINSON, R.S. A synopsis of anaesthesia, 7th ed., p. 828. Bristol: John Wright and Sons Ltd. (1973).

3. SNow, J.C., Kripke, B.J., Norton, M.L. et al. Corneal injuries during general anesthesia. Anesth. Analg. 54: 465-467 (1975).

4. Terry, H.R., Kearn, T.P., Love, J.G. et al. Untoward opthalmic and neurologic events of anesthesia. Surg. Clin. in North Am. 45 No 4: 927-937 (1965).

5. Cross, D.A. \& Krupin, T. Implications of the effects of general anesthesia on basal tear production. Anesth. Analg. 56: 35-37 (1977).

6. Norn, M.S. Wetting time. Acta Ophthalmol. Suppl. 525: 42-43 (1975).

7. BundgaARd-Nielsen, P., Bøggild-Madsen, N.B. \& HAMmer, U. The development of an opthalmic ointment for the protection of the eyes during anaesthesia. Arch. Pharm. Cherni., Sci. ed. 6: 121-126 (1978).

8. Atkinson, R.S., Rushman, G.B.\& LeE, J.A. A synopsis of anaesthesia, 81h ed., p. 213. Bristol: John Wright and Sons Ltd. (1977).

9. Sмiтh, R.M. Anesthesia for infants and children. 3rd ed., p. 349. London: The C. V Mosby Company (1968).

10. Pharmacopoea Nordica, Editio Danica, Copenhagen 3: 243 (1963).

11. Goodman, L.S. \& Gilman, A. The pharmacological basis of therapeutics, 4th ed., pp. 987-988. 1026, 1713, London: The Macmillan Company (1970).

12. Jones, L.T. The lacrimal secretory system and its treatment. Am. J. Ophthalmol. 62: 47-60 (1966).

\section{RÉSUMÉ:}

On a évalué sur 120 patients anesthésiés pour au moins 90 minutes la protection oculaire accordée par une application de paraffine Ph. Nord. 63, dans un oeil alors que de la méthylcellulose à $4 \%$ en solution aqueuse était appliquée dans l'autre. On a utilisé l'anesthésie à l'halothane ou au thiopentone associé à la meperidine, ou une neuroleptanesthésie. L'oedème péri-occulaire et la réaction conjonctivale ont été moins marqués avec l'emploi de la méthylcellulose. Lorsqu'on associait l'onguent à base de parraffine à l'anesthésie à l'halothane, on a noté des signes d'interactions médicamenteuses manifestées par une rougueur importante de la conjonctive. Pour les trois types d'anesthésie, la méthylcellulose a produit un accolement ferme des paupières de sorte que l'oeil ne s'est pas asséché et a été protégé des corps étrangers et des abrasions de la cornée. La méthylcellulose n'a pas produit d'effets secondaires. Les auteurs en concluent que la méthylcellulose à 4 pour cent produit une meilleure protection occulaire que la paraffine pendant l'anesthésie générale. 